January 2005

\title{
Who Are Those Guys? - An Empirical Examination of Medical Malpractice Plaintiffs' Attorneys
}

Catherine T. Harris

Ralph Peeples

Thomas B. Metzloff

\section{Recommended Citation}

Catherine T. Harris et al., Who Are Those Guys? - An Empirical Examination of Medical Malpractice Plaintiffs' Attorneys, 58 SMU L. REv. 225 (2005)

https://scholar.smu.edu/smulr/vol58/iss2/2

This Article is brought to you for free and open access by the Law Journals at SMU Scholar. It has been accepted for inclusion in SMU Law Review by an authorized administrator of SMU Scholar. For more information, please visit http://digitalrepository.smu.edu. 


\title{
Who Are Those Guys? An Empirical Examination of MEdical Malpractice Plaintiffs' Attorneys
}

\author{
Catherine T. Harris* \\ Ralph Peeples** \\ Thomas B. Metzloff***
}

\section{INTRODUCTION}

7 TORT reform and medical malpractice litigation are once again in the news. Medical malpractice insurance premiums increase dramatically. Physicians complain. Insurers blame the tort system and invoke the litany of rapidly escalating jury awards won by those grasping for straws and rapacious plaintiffs' lawyers. National and local medical associations call for reform, while physicians in high-risk specialties talk about curtailing or even abandoning their practices. ${ }^{1}$ Calls for "tort reform" become louder and more insistent as President George W. Bush takes up the call for changes such as dollar caps on the amount of noneconomic damages that a jury may award. ${ }^{2}$ Across the nation, bills are introduced at the federal and state level to impose limitations on medical malpractice litigation. ${ }^{3}$ Plaintiffs' lawyers, and some insurance industry

* Wake Forest University. This research was supported with funding from the Robert Wood Johnson Foundation, Princeton, New Jersey, Grant I.D. \#027071. The authors gratefully acknowledge the assistance of Professor Michael Green, Wake Forest University School of Law. Direct all correspondence to Ralph Peeples, Box 7206, Wake Forest University School of Law, Winston-Salem, North Carolina 27109. E-mail: rpeeples@law.wfu.edu.

** Wake Forest University School of Law.

*** Duke University School of Law.

1. See, e.g., Sheri Hall, Malpractice Rates Drive Off Doctors, Detrort News, Oct. 25, 2004, at A1; American College of Obstetricians and Gynecologists, News Release, Medical Liability Survey Reaffirms More Ob-Gyns Are Quitting Obstetrics (July 16, 2004), available at www.Acog.org/from_home/publications/press_releases/nr07-16-04.cfm (last visited Feb. 21, 2005); American Medical Association, Medical Liability Reform- Now! at 5-7 (2004), available at http://www.ama-assn.org/go/mlmow (last visited Feb. 21, 2005). For a thoughtful and concise discussion of the problem of medical malpractice, see David Studdert et al., Medical Malpractice, 350 NEw ENG. J. Med. 283 (2004).

2. See, e.g., Peter Baker, Bush Campaigns to Curb Lawsuits; President Says 'Junk' Litigation is Driving Small-Town Doctors Out of Business, Washington Post, Jan. 6, 2005, at A1; Tanya Albert, Bush Stumping for Liability Reform in "Judicial Hellhole," AMEDNEws.COM (Jan. 24, 2005), at http://www.ama-assn.org/amednews/2005/01/24/ gusb0124.htm (last visited Feb. 18, 2005).

3. See, e.g., Tanya Albert, Doctors to Storm States for Tort Reform, Amednews.Com (Jan. 17, 2005), at http://www.ama-assn.org/amednews/2005/01/gvsa0117.htm (last visited Feb. 18, 2005); Stephanie Francis Ward \& Siobhan Morrissey, Tort Reform Gaining Traction: Lawyers Predict Election Success Will Spur Federal Efforts, ABA Journal E-RE- 
critics have countered by blaming insurers for the crisis. ${ }^{4}$

Setting aside the question of who has the better side of the debate, it is nonetheless clear that plaintiffs' attorneys are, and will remain, the focus of much attention and considerable criticism. ${ }^{5}$ They are, after all, the ones who bring the lawsuits, and they are the ones who are perceived as obtaining the large settlements and the sometimes even larger jury awards. What do we really know about these people? It is a topic where anecdote and surmise dominate. ${ }^{6}$ Little empirical evidence exists that considers what are the characteristics of successful (and not so successful) plaintiffs' lawyers.

In this paper, we focus on the impact that the characteristics of plaintiffs' lawyers have on the outcome of medical malpractice cases. We approach our analysis from the perspective of the plaintiff and her counsel. This perspective is an important one. Because of the nature of medical malpractice litigation, there will be substantial gaps in what the plaintiff and her lawyer know about the case. Unlike the defendant physician and the defendant physician's insurer, plaintiffs do not have access to a wide range of outside physician reviewers and experts. This asymmetry of information ${ }^{7}$ is critical because the focus in most medical malpractice cases

PORT (Nov. 5, 2004), at http://www.abanet.org/journal/ereport/nov5tort.html (last visited Feb. 18, 2005). Several states, including Florida, Idaho, Mississippi, Ohio, Oklahoma, Texas, and West Virginia, enacted legislation in 2003 and 2004 aimed at reforming medical malpractice litigation. See Nat'l Conference of State Legislatures, Backgrounder: Medial Malpractice (Oct. 2004), available at http://www.ncsl.org/programs/press/2004/back groundermedmal.html (last visited Apr. 13, 2005). In early 2005, Missouri, South Carolina, Montana, and Virginia also enacted medical malpractice ligislation. Mike Norbut, Physicians in Four States Score Tort Reform Wins, Amednews.com (Apr. 18, 2005), at www.ameasson.org/adedraws/2005/04/18/gvsa.0418.htm. At the federal level, the House of Representatives passed H.R. 4280, the Health Act, in May 2004. One of the key features of the bill was the imposition of a cap on non-economic damages. The Senate, to date, has not approved the bill. H.R. 4280, 108th Cong. $\S 54(\mathrm{c})$ (2d Sess. 2004), available at http:// www.thomas.loc.gov.

4. See, e.g., Americans for Insurance Reform, Medical Malpractice Insurance: Stable Losses/Unstable Rates (Oct. 12, 2004), available at http://www.insurance-reform.org; J. Robert Hunter and JoAnne Doroshow, Premium Deceit (1999), available at www.centerjd.org/PremiumDeceit/\%20.pdf. See also Robert J. Bingle, Reform Insurance Industry, Not Legal System, CHIC. TriB., Jan. 29, 2003 at 16 (letter to the editor from the President of the Illinois Trial Lawyers Association); Bob Herbert, Malpractice Myths, N.Y. Times, June 21, 2004 (op-ed.); Rachel Zimmerman and Christopher Oster, Assigning Liability: Insurers' Missteps Helped Provoke Malpractice 'Crisis', WALL ST. J., June 24, 2002, at A1.

5. See, e.g., Office of the Assistant Secretary for Planning and Evaluation, U.S. Department of Health and Human Services, Addressing the New Health Care Crisis: Reforming the Medical Litigation System to Improve the Qualtry of Health CARE 15 (2003); Herbert M. Kritzer, From Litigators of Ordinary Cases to Litigators of Extraordinary Cases: Stratification of the Plaintiffs' Bar in the TwentyFirst Century, 51 DePAul L. Rev. 219, 220 (2001); Paul C. Weiler, Fixing the Tail: the Place of Malpractice in Health Care Reform, 47 Rutgers L. Rev. 1157, 1158 (1995).

6. See David Hyman, Medical Malpractice and the Tort System: What Do We Know and What (If Anything) Should We Do About It?, 80 Tex. L. Rev. 1639, $1639-40$ (2002).

7. Frank A. Sloan \& Chee Ruey Hsieh, Variability in Medical Malpractice Payments: Is the Compensation Fair? 24 LAw \& SoC'Y REv. 997, 1001 (1990). 
is breach of the standard of care, a subject usually left to experts. ${ }^{8}$ Thus, while defendant physicians and their insurers may be able to predict outcome in terms of liability early on in the litigation, the same is often not true for plaintiffs and their lawyers.

Lawyers believe that the identity of counsel makes a difference in terms of case outcomes. Reflexively, lawyers believe that it is important for a client to be represented by a "good" lawyer, not just a "competent" lawyer. In other words, it matters who the plaintiff's lawyer is, and who the defendant's lawyer is. Presumably, most clients also believe so. The proposition is not self-evident, however. Do the lawyers really matter? This is a threshold issue that must be addressed.

Earlier studies of medical malpractice litigation imply that the identity of the lawyers involved does not really matter. Instead, much of the literature suggests that it is the apparent negligence of the defendant physician that predicts outcome. For example, a 1992 study of New Jersey medical malpractice claims concluded that compensation for such claims is closely associated with a finding of probable liability on the part of the defendant physician, as determined by peer review - with no input from counsel. ${ }^{9}$ Similarly, other studies in Florida ${ }^{10}$ and Chicago ${ }^{11}$ found a simple connection between negligence, as determined by other physicians, and compensation to the claimant. Likewise, a national study of anesthesiology claims found a strong link between negligence, as determined by physician reviewers, and compensation. ${ }^{12}$ The implication of these studies is that the central event in a rational system of claims resolution should be a determination of medical fault by a panel of experts, based upon a review of the relevant medical records. ${ }^{13}$ The role of lawyers in such a system would not be of great importance, particularly if a schedule of compensation for specified injuries were to be adopted.

Other researchers have concluded that "fault" is not nearly as significant as severity of injury. For example, a study conducted in the late 1980 s in the State of New York found that whether any compensation at all was paid to the claimant was tied to severity of injury, defined in terms of temporary or permanent disability. ${ }^{14}$ Whether the treating physician had been negligent, however, was not linked to compensation. ${ }^{15}$ This finding - a follow-up study to the larger and widely known Harvard Med-

8. Dan B. Dobbs, The Law Of Torts $\S 242,639$ (2000); Paul C. Weiler, MediCal Malpractice ON Trial 19 (1991). See also Sara Rosenbaum, The Impact of United States Law on Medicine as a Profession, 289 JAMA 1546, 1551 (2003).

9. Mark Taragin et al., The Influence of Standard of Care and Severity of Injury on the Resolution of Medical Malpractice Claims, 117 ANNALs INTERNAL MED. 780 (1992).

10. Sloan \& Hsieh, supra note 7, at 1014.

11. Henry S. Farber \& Michelle J. White, A Comparison of Formal and Informal Dispute Resolution in Medical Malpractice, 23 J. LeGal STUd. 777, 798 (1994).

12. Frederick W. Cheney et al., Standard of Care and Anesthesia Liability, 261 JAMA 1599, 1601 (1989).

13. Taragin et al., supra note 9 , at 783 .

14. Troyen A. Brennan et al., Relation Between Negligent Adverse Events and the Outcomes of Medical Malpractice Litigation, 335 NEw ENG. J. MED. 1963, 1965 (1996).

15. Id. 
ical Practice Study ${ }^{16}$ - has been frequently cited in the recent debate over the need for tort reform. ${ }^{17}$ Again, if severity of injury is the crucial variable, the role of lawyers would be peripheral, at best.

Even if compensation is tied to the determination of negligence, however, this finding has some obvious limitations as a useful predictor of outcomes. First, the studies uniformly assume that it is the liability determination of the defendant's insurer that matters, not the assessment of the plaintiff's counsel. ${ }^{18}$ After all, it is the insurer who ultimately writes the check. Even the assessment by the defendant's counsel is likely to be a function of the insurer's own determination. ${ }^{19}$ Thus, for all but the insurer (and perhaps the defendant's counsel), the assessment of liability will not be known and will certainly not be discoverable by the plaintiff's counsel. The insurer's assessment of liability may be a reliable predictor of whether money is paid (either in settlement or following a plaintiff's verdict), but from the plaintiff's perspective-from the perspective of the person who decides whether to sue, in other words-it is not a useful forecasting tool. ${ }^{20}$ Second, factors other than a conclusion of medical negligence can affect case outcomes. The decision whether to settle is made against the predicted outcome at trial. ${ }^{21}$ Outcomes at trial can be affected by the appearance and credibility of witnesses, as well as the trial skills of opposing counsel. These are factors not related to determinations of negligence and causation. Because of these limitations, we set out to determine whether predictions of case outcomes can be made independently of liability assessment. Specifically, we wanted to see if the identity of the

16. The Harvard Medical Practice Study was a population-based study of adverse events in hospitalized patients. The study produced several books and numerous articles. See, e.g., Weiler, supra note 8; Paul C. Weiler et al., A Measure of Malpractice: Medical Injury, Malpractice Litigation, and Patient Compensation (1993); Kenneth Abraham \& Paul Weiler, Enterprise Liability for Health Care, 108 Harv. L. REv. 381 (1994); Troyen Brennan et al., Incidence of Adverse Events and Negligence in Hospitalized Patients: Results of the Harvard Medical Practice Study I, 324 New ENG. J. MED. 370 (1991); Brennan et al., supra note 14; Lucian Leape et al., The Nature of Adverse Events in Hospitalized Patients: Results of the Harvard Medical Practice Study II, 324 NEw ENG. J. MED. 377 (1991).

17. See, e.g., U.S. Department of Health and Human Services, Office of the Assistant Secretary for Planning and Evaluation, supra note 5, at $8 \mathrm{n} .45$ (2003); Yank Coble, Tragedy and Torts: Bankrupting Medicine Not the Answer, AM. MED. News, March 17, 2003 (opinion column by Dr. Coble, the President of the AMA); Hyman, supra note 6, at 1643; Bryan A. Liang, Error in Medicine: Legal Impediments to U.S. Reform, 24 J. Health Pol., PoL'y \& L. 27,36 (1999); Michelle Mello \& Troyen Brennan, Deterrence of Medical Errors: Theory and Evidence for Malpractice Reform, 80 TEX. L. REv. 1595, 1619 (2002).

18. Cheney et al., supra note 12, at 1599; Taragin et al., supra note 9, at 780 .

19. For a description of the claims resolution process from the insurer's perspective, see Ralph Peeples et al., The Process of Managing Medical Malpractice Cases: The Role of Standard of Care, 37 WAKE ForEST L. REV. 877, 880, 885 (2002).

20. See Weiler, supra note 5, at 1162. It is often difficult for plaintiffs and their counsel to tell if the injury in question was the result of medical malpractice.

21. See Samuel Gross \& Kent Syverud, Don't Try: Civil Jury Verdicts in a System Geared to Settlement, 44 UCLA L. REv. 1, 4 (1996); Herbert Kritzer, Contingent-Fee Lawyers and Their Clients: Settlement Expectations, Settlement Realities, and Issues of Control in the Lawyer-Client Relationship, 23 LAW \& SoC. INQUIRY 795, 801 (1998). 
plaintiff's attorney predicts case outcomes. In addition, we wanted to see if severity of injury, by itself, is a reliable predictor of case outcomes.

Assuming that the identity of plaintiff's counsel does make a difference, an additional problem awaits. How can the effectiveness of the plaintiff's counsel be measured? What do skilled plaintiffs' lawyers look like? Research on the effect that the skill and competence of lawyers have on case outcomes is very limited. As Professors Heinz and Laumann observed twenty five years ago, the profession of law is less studied and less understood than the practice of medicine. ${ }^{22}$ While scholars have devoted more attention to the nature of the practice of law since that time, ${ }^{23}$ there is still much that we do not know about the profession. For example, while studies by sociologists and others address such issues as professional stratification ${ }^{24}$ and specialization, ${ }^{25}$ the relative importance of competence and skill in predicting case outcomes has rarely been considered. ${ }^{26}$

The lack of serious study of the effect of legal competence and skill is not surprising. Measuring competence and skill is difficult, as is the task of determining actual case outcomes with precision. ${ }^{27}$ The evidence that exists on the subject suggests that case evaluation and negotiation skills make a difference in case outcomes, ${ }^{28}$ as does specialization. ${ }^{29}$ In the context of medical malpractice, a landmark study of obstetrical and emergency room malpractice claims in Florida led by Professor Frank Sloan suggested that the skill of the lawyer for the plaintiff might be a factor in

22. John P. Heinz \& Edward O. Laumann, The Legal Profession: Client Interests, Professional Roles, and Social Hierarchies, 76 MicH. L. REV. 1111, 1111 (1978).

23. For a representative summary of scholarly examination of the legal profession, see Herbert Kritzer, The Justice Broker: Lawyers and Ordinary Litigation 4, 6 (1990).

24. See, e.g., Jerome E. Carlin, Lawyers on Their OWn (1994); H. Laurence Ross, SETTLED Out of Court 74 (1970); Richard L. Abel, The Transformation of the American Legal Profession, 20 LAw \& Soc'Y Rev. 7, 12-13 (1986); Kritzer, supra note 5, at 220-23; Jack Ladinsky, Careers of Lawyers, Law Practice and Legal Institutions, 27 АM. Soc. Rev. 47, 53 (1963); Rebecca L. Sandefur, Work and Honor in the Law: Prestige and the Division of Lawyers' Labor, 66 AM. Socio. Rev. 382, 382-83 (2001).

25. See, e.g., Jerome E. Carlin, Lawyers' Ethics 11-13 (1966); Douglas E. Rosenthal, LAWYeR AND Client: Who's IN Charge? 134 (1977); Ross, supra note 24, at 73 76; Stephen Daniels \& Joanne Martin, It Was the Best of Times, It Was the Worst of Times: The Precarious Nature of Plaintiffs' Practice in Texas, 80 TEX. L. REv. 1781, 1785-95 (2002); John. P. Heinz et al., The Changing Character of Lawyers' Work: Chicago in 1975 and 1995, 32 LAW \& SOC'Y REV. 751, 760-61 (1998); Edward O. Laumann et al., Washington Lawyers and Others: The Structure of Washington Representation, 37 STAN. L. REV. 465, 488-89 (1985).

26. But see Stephen Daniels et al., Why Kill All the Lawyers? Repeat Players and Strategic Advantage in Medical Malpractice Claims, AM. BAR Found. WORKIng PAPER \#9210 (1993).

27. For a discussion of the difficulties involved, and a description of possible methods of evaluation, see Douglas E. Rosenthal, Evaluating The Competence of Lawyers, 11 LAw \& SOC'Y REV. 257 (1976). See also the discussion of evaluation methods based on outcomes in KRITZER, supra note 23, at 135-57.

28. Herbert Kritzer, Let's Make a Deal $54-55$ (1991); Gerald R. Williams, Legal Negotiation and Settlement 5-7 (1983).

29. Rosenthal, supra note 25 , at 134 . 
determining the outcome of specific cases. ${ }^{30}$ The researchers found that claimants represented by "specialist" attorneys fared better than did claimants represented by non-specialist attorneys, in terms of amount recovered. ${ }^{31}$ The researchers further observed that the relative importance of who the lawyers are in a particular case had never been the subject of empirical study. ${ }^{32}$ The measurement of the impact of specialist attorneys on case outcomes introduced an important new dimension to an understanding of the litigation process. However, the impact of specialist attorneys was not the principal focus of the study. The study used a number of different criteria, both objective and subjective, for determining specialist status. ${ }^{33}$ The impact of specific attorney attributes other than "specialist" status was not studied. In addition, the study considered only the influence of the plaintiff's counsel on case outcomes. The effect of the plaintiff's counsel's interaction with the defendant's counsel was not discussed.

As sparse as the literature is on the subject of lawyer skill and competence, there is even less discussion to be found on the consequences of confrontation between lawyers with different levels of skill and competence. This lack of study is unfortunate since lawyers do not try or settle cases in isolation. The identity of opposing counsel, in other words, might matter as well.

Our study begins, then, with two related queries: (1) Can the outcome of medical malpractice cases be predicted, without reference to assessments of liability, by focusing on the competence and skill of the lawyer for the plaintiff?; and (2) What measure can be used for determining competence and skill? The answers to these two queries will lead to a better understanding of the attributes of successful plaintiff's lawyers.

\section{METHODS}

\section{A. The SAMPLe}

As is true for virtually all empirical studies of medical malpractice, our data are drawn from a single state. We believe our findings can be readily generalized beyond the borders of North Carolina. Our data reflect the individual determinations as to payment (or non-payment) of claims by a number of private medical malpractice insurers, many of whom do business in more than one state. The insurers represent a blend of both physician-owned and investor-owned liability companies. North Carolina is a demographically diverse state and is the tenth most populous state in the

30. Frank A. Sloan et al., Suing for Medical Malpractice 154, 170, 181-82 (1993).

31. Id. at 196.

32. Id. at 164 .

33. Specialists were defined to include attorneys who had handled four or more medical malpractice cases, whether in or out of the sample, as well as their partners and associate attorneys; lawyers listed as experts in tort law in The Best Lawyers in America, members of the Inner Circle of Advocates; and attorneys who identified themselves as medical malpractice specialists in the Martindale-Hubbell National Directory of Lawyers. SlOAN ET AL., supra note 30, at 170. 
Union. There is nothing about North Carolina medical malpractice law that places it outside the mainstream.

Our study is based on the collected data from 348 medical malpractice lawsuits filed in the North Carolina courts between 1992 and 1995. Information about these cases was obtained through a combination of techniques. First, the actual court file for each case was retrieved, read, and summarized. As a result, for each case we were able to determine the nature of the plaintiff's claim, the severity of the alleged injury, and the identity of the lawyers for the plaintiff and the defendant. From the court files we were also able to determine the final disposition of each case, such as whether the case went to trial, or was simply dismissed.

However, court records have their limitations. They rarely indicate whether a monetary settlement was reached, and they almost never disclose the actual amount of any settlement. Instead, court records will indicate either that a case was voluntarily dismissed-either with or without prejudice-or that judgment was entered in favor of the defendant or the plaintiff, usually following a jury trial. These are serious shortcomings, since most civil cases, including malpractice cases, settle before trial. ${ }^{34}$ To address these shortcomings, we surveyed and interviewed attorneys involved in each case, in order to determine whether money was paid to the plaintiff and, if so, how much. By comparing and matching data gathered from the court records and from attorney interviews, we were able to determine the "real" outcomes for the cases in the sample. In most cases ( 296 out of 348 cases or $85.1 \%$ of cases), if money had actually been paid to the plaintiff and whether the payment was made as part of a settlement or as the result of a favorable verdict. We also collected basic demographic information for each attorney, including: city of practice, number of years admitted to practice, law school attended, and gender. Although we had 322 usable cases, totals for each analysis will vary since each variable in our analysis had some missing values. ${ }^{35}$

The selection of cases studied was not random. Our sample consisted of cases that were ordered to mediation by the trial court under the auspices of what was at the time a pilot program of mediated settlement conferences mandated by the North Carolina General Assembly. ${ }^{36}$ In all, eighteen counties were included in the pilot study. The pilot counties included

34. See, e.g., Patricia M. Danzon, Medical Malpractice 42 (1985); Patricia M. Danzon and Lee A. Lillard, Settlement Out of Court: The Disposition of Medical Malpractice Claims, 12 J. of Legal Stud. 345, 347-48 (1983); Marc Galanter \& Mia Cahill, "Most Cases Settle": Judicial Promotion and Regulation of Settlements, 46 STAN. L. Rev. 1339, 1339-40 (1994); Sloan \& Hsieh, supra note 7, at 1005; Gross \& Syverud, supra note 21, at 2.

35. Missing values occur in any study when information is unavailable for some cases in a given analysis. When this occurs these cases are excluded from the analysis.

36. Sess. Laws 207 (N.C. 1991) (codified as N.C. GeN. STAT. § 7A-38 (1991) (repealed 1995)). In 1991, the General Assembly instructed the Administrative Office of the Courts to implement a program of mandatory mediated settlement conferences in selected counties around the state. The program became statewide as of 1995. See N.C. Gen. Stat. \$ 7A-38.1 (Supp. 2004). For general background on the North Carolina program, see Comment, Good Faith Mediation: Improving Efficiency, Cost, and Satisfaction in North Carolina's Pre-trial Process, 18 CAmpbell L. Rev. 281 (1996); Comment, An End to Settle- 
five of the six most populous cities in the state (Charlotte, Raleigh, Greensboro, Winston-Salem, and High Point). Because the sample consisted of cases that had advanced far enough in the litigation process to be ordered to mediation, ${ }^{37}$ the sample is probably weighted in favor of durable cases, that is, cases that have progressed beyond the initial stages of complaint and answer. It is likely that the sample excludes many, if not most, frivolous cases.

\section{B. The Measure of Effective Plaintiff's Counsel}

We collected data on three general types of case outcomes: abandoned cases, trials, and settlements. While other outcomes are possible, ${ }^{38}$ these three outcomes account for the vast majority of the cases in our sample (see Table 1, Outcomes). These three outcomes are all relevant to a determination of the effectiveness of the plaintiff's counsel, but each has its drawbacks as a measure of effectiveness. Abandoned cases-i.e., cases unilaterally dropped by the plaintiff-are relevant because they represent cases in which the plaintiff's counsel failed to obtain money for his or her client, for whatever reason. Obviously, though, such cases tell us little about the conditions that lead to the payment of money. ${ }^{39}$ The number or rate of trials can be misleading simply because trials are quite uncommon in medical malpractice litigation. ${ }^{40}$ Furthermore, an examination of cases that actually make it to trial yields a skewed and unrepresentative picture, since it does not take into account the "selection effect" of settlement. ${ }^{41}$ Settlement is a more common event too frequent to be ignored. Yet settlement rate, by itself, can be misleading because it ignores the impact of an occasional trial. In addition, reliance on court records as evidence of settlement is sometimes misplaced. While a voluntary dismissal with prejudice notation in the court file often indicates a monetary settlement, this is not always the case. For example, a plaintiff's attorney who has decided not to pursue a filed lawsuit might agree to file a voluntary dismissal with prejudice in exchange for a promise from the defense counsel not to seek reimbursement of costs. Such an arrangement is more

ment on the Courthouse Steps? Mediated Settlement Conference in North Carolina Superior Courts, 71 N.C. L. REv. 1857 (1993).

37. Mediated Setrlement Conf. Rule 1B.(2) states that the Senior Resident Superior Court Judge is to issue the order for the mediated settlement conference "as soon as practicable after the time for the filing of answers has expired." Thus, in order for a case to be ordered to mediation, at least a complaint and answer will have been filed.

38. For example, summary judgment and dismissal by court order for failure to prosecute the claim.

39. The usual sign of an abandoned case is a voluntary dismissal without prejudice. While it is true that a case voluntarily dismissed without prejudice may be later refiled, after tracking all voluntary dismissals without prejudice for at least one year, we found that most such cases were not refiled.

40. See Table 1. See also DAnzon, supra note 34, at 42; SLOAN ET AL., supra note 30 , at 165-67; Farber \& White, supra note 11, at 799-802; Thomas B. Metzloff, Resolving Medical Malpractice Disputes: Imaging the Jury's Shadow, 54 Law \& CONTEMP. ProBs. 43, 49 (1991).

41. Kevin Clermont \& Theodore Eisenberg, Litigation Realities, 88 CoRnell L. Rev. $119,137-38$ (2002). 
in the nature of a negotiated surrender, than a true bargained-for settlement. As a result, we focused our attention on a single measure: whether money was paid to the plaintiff either in settlement or as the result of a verdict following trial.

The reason for the decision to measure plaintiffs' lawyers' skill in terms of whether money was paid to the plaintiff was simple. Our analysis looks primarily at plaintiffs' attorneys, and plaintiffs' attorneys are compensated only when money is obtained for their clients. The fact that money was obtained in a given case thus takes on tremendous importance. While a very competent plaintiff's lawyer might end up taking (and trying) her case to verdict, the decision to proceed to trial will not be made lightly. Defendant physicians win at trial much more often than plaintiff patients do, ${ }^{42}$ and plaintiffs' lawyers are aware of that fact. Nonetheless, sometimes plaintiffs do win at trial. In recognition of that possibility, it was important to include verdicts for the plaintiff in our measure of attorney effectiveness. Our assumption is, then, that more effective plaintiffs' lawyers obtain money for their clients more often than less effective plaintiffs' lawyers do. In short, what matters is money.

Other more sophisticated measures of effectiveness can be devised. For example, it would be useful to compare settlement amounts, while controlling for severity of the injury alleged. In our sample, however, we found that while it was usually possible to determine whether money was paid, it was not always possible to determine the actual amount paid. A common condition of settlement is a pledge extracted from the plaintiff not to disclose the settlement amount. Although we were able to obtain actual settlement amounts for some cases, an insufficient number of such cases precluded a detailed analysis of the results.

\section{VARIABles Examined}

We examined a number of different variables in order to determine: (1) Whether the identity of the plaintiff's attorney matters?; and (2) If so, what attributes of successful plaintiffs' attorneys make a difference? We considered the impact of both single variables and combination variables on payment and trial rates. Combination variables included (1) characteristics of attorneys and (2) case attributes. The variables are described below and summarized in Figure 1.

Severity of Injury

Some cases involve very serious injuries while others involve less significant harm. It is possible that the dynamics of resolution for cases involving a very severe injury will differ from those cases involving only a modest or temporary injury. Indeed, some researchers have found that severity of injury does affect settlement rates. ${ }^{43}$ We identified nine different levels of severity of injury ranging from emotional injury to death,

42. Farber \& White, supra note 11, at 802; Metzloff, supra note 40, at 50; Peeples et al., supra note 19 , at $890-91$.

43. See generally, Brennan et al., supra note 14. 
based on the nine-stage scale used by the National Association of Insurance Commissioners. ${ }^{44}$ For each case we determined the severity of the alleged injury based on the contents of the complaint. We then created two separate, binary variables. ${ }^{45}$ The first variable used the categories more severe, coded as " 1 " and less severe, coded as " 0 ." The second variable used the categories "death," coded as " 1 " and all other injuries, coded as "0."

\section{Hospital Defendant}

Malpractice lawsuits sometimes name a hospital as a defendant either alone or as one of several defendants. The presence of a hospital as a defendant might affect the likelihood of money being paid to the plaintiff. For example, an institution such as a hospital might not be perceived as a sympathetic defendant at trial, especially when compared to individual physician defendants. In addition, unlike physicians, hospitals are not subject to the mandatory reporting requirements of the National Practitioner Data Bank. ${ }^{46}$ Therefore, the incentive to avoid making any payment in settlement, no matter how modest, in order to stay out of the Data Bank does not exist for hospitals. We created a binary variable to identify cases in which a hospital was a defendant, coded as " 1 " for cases in which a hospital was a defendant or a codefendant, and coded as " 0 " for cases in which a hospital was not a defendant or codefendant.

\section{Gender}

The gender classification for plaintiffs' lawyers was, of course, straightforward. We created a binary variable with "male" coded as " 1 " and "female" coded as " 0 ," in order to see if the gender of plaintiffs' lawyers had any impact on case outcome.

\section{Law School Attended}

The categories used for law school attended consisted of the five law schools located in North Carolina (UNC, Wake Forest, Duke, Campbell and North Carolina Central) and a separate category for "out of state" law schools. Because medical malpractice law, like personal injury law in general, is a function of state rather than federal law, we wanted to see if attending a law school in or outside of the state of North Carolina made any difference. Recognizing that personal and professional relationships are often made in law school we also wanted to look for evidence of

44. National Association of Insurance Commissioners, NaIC Malpractice Claims: 1975-78 (1980), reproduced in Sloan \& Hsieh, supra note 7, at 1004. The NAIC scale is widely used as a standard measure for severity of injury. See, e.g., Sloan ET AL., supra note 30 , at $22-23$.

45. A binary variable simply consists of a variable with only two categories, such as " 0 / 1 " or "yes/no."

46. Health Care Quality Improvement Act of 1986, 42 U.S.C. \& 11131 (1994). The National Practitioner Data Bank was established by Congress in title IV, section 421 of the Public Law 99-660. Under the Act, any amount paid by an insurer on behalf of a physician must be reported to the Data Bank. Whether liability was established is irrelevant. For a description of the National Practitioner Data Bank see Ilene D. Johnson, Reports to the National Practitioner Data Bank, 265 JAMA 407 (1991); Elisabeth Ryzen, The National Practitioner Data Bank: Problems and Proposed Reforms, 13 J. LEG. MED. 409 (1992). 
"networking." We created a binary variable with "in-state law school" coded as " 1 " and "out of state law school" coded as " 0 ." In addition, when an attorney attended an in-state law school, we identified the particular school attended.

\section{General Experience of the Plaintiff's Counsel}

Experience is widely thought to be a desirable trait in a lawyer. To test this assumption, we measured the general experience of the plaintiffs' counsel against actual case outcomes. Attorney directories provide information on the year attorneys were first admitted to practice. Using this data we determined the number of years each attorney had been in practice, thus giving a measure of general practice experience. We also developed a binary variable. " 0 " was used to represent "younger" lawyers with less than ten years from first admission to practice at the time of the study. Ten or more years in practice was defined as "older" and coded as "1." The distinction was based on the greatest length of time it might take for a newly licensed attorney to be considered for partnership in his or her law firm. That is, within ten years out of law school, an attorney has had time to prove or not prove himself. We also created a similar binary variable for defense counsel with the same criteria and coding.

Specific Experience in Medical Malpractice Litigation

Apart from general practice experience, the level of specific experience in handling medical malpractice cases may also be associated with specific case outcomes. After all, medical malpractice litigation is largely a specialty practice for lawyers, especially on the defense side. We noted relatively few defense attorneys in our sample with a high concentration of cases handled by a small number of attorneys. For example, less than twenty percent of the defense lawyers in our sample ( 15 out of 89 lawyers or $16.9 \%$ ) accounted for more than half of the cases (188 out of 348 cases or $54.0 \%$ ). Less than ten percent of all defense lawyers (8 out of 89 lawyers or $9 \%$ ) accounted for almost forty percent of the cases (137 out of 348 cases or $39.4 \%$ ). On the plaintiffs' side the number of cases handled by a small number of attorneys is also striking, although the overall level of concentration was not as great. About seven percent of all plaintiffs' lawyers (12 out of 179 lawyers or $6.7 \%$ ) accounted for more than thirty percent of the cases (105 out of 348 cases or $30.2 \%$ ). This suggests that plaintiffs often make a conscious effort to seek out proven specialists. It is also possible, of course, that attorneys who do not specialize in medical malpractice will refer the client to an attorney with a reputation for handling such cases. ${ }^{47}$ Market principles also are at work. Medical malpractice is a subset of personal injury law, an area of practice for which plaintiffs' attorneys are invariably compensated on a contingent fee basis. Only if the case yields a payment to the plaintiff does the plaintiff's counsel collect a fee. It follows, then, that plaintiffs' attorneys who have handled comparatively more medical malpractice cases have demonstrated

47. See, e.g., SLOAN ET AL., supra note 30 , at 75-76; see generally Daniels \& Martin, supra note 25 , at $1793-95$. 
their skill in this field, to their own economic satisfaction, and perhaps to the satisfaction of clients as well. However, it is important to keep in mind that anyone with a willing client can be a plaintiff's lawyer. ${ }^{48}$ The same is not true on the defense side where defense lawyers are retained by the insurer.

We developed a binary variable of " 1 " for cases handled by attorneys who had managed four or more cases during the study period labeled "more case experience" and " 0 " for cases handled by attorneys who had managed less than four cases labeled "less case experience." In effect, this criterion required counsel to have handled on average at least one medical malpractice case per year in order to be labeled as having more case experience..$^{49} \mathrm{~A}$ mirror variable for defense counsel was also created, using the same criteria and coding.

\section{Trial Experience}

While intuitively one would assume that trial experience would be an important attribute for plaintiffs' lawyers to have, we wanted to test that assumption. In order to measure trial experience, we created a binary variable for trial experience. Cases handled by an attorney who had conducted at least one medical malpractice trial during the study period were coded as " 1 ," trial experience. Cases handled by an attorney who had not conducted a medical malpractice trial during the study period were coded as " 0 ," no trial experience.

\section{Seasoned Attorneys}

If we are to isolate the characteristics of the most successful plaintiffs' counsel, we must consider their characteristics in combination to determine if there is an "additive effect." We defined "seasoned attorneys" as those attorneys who (1) had handled at least four medical malpractice cases; (2) had conducted at least one medical malpractice trial during the study period; and (3) had attended law school within the state of North Carolina. This determination was made for both plaintiffs' and defendants' counsel. Cases handled by a "seasoned attorney" were coded as " 1. " Cases not handled by a seasoned attorney were coded as " 0 ."

\section{High Percentage Cases}

Case attributes can also be considered in combination. It may be, for example, that when a case possesses two particular attributes, payment of money becomes more likely. In order to examine this possibility, we defined "high percentage cases" as those alleging a more severe injury and in which a hospital is either a defendant or a co-defendant. Cases meeting both criteria were coded as " 1 ," high percentage cases. Cases not meeting both criteria were coded as " $0 . " 50$

48. See Heinz et al., supra note 25 , at 772 .

49. This criterion is similar to one of the criteria used by Sloan et al. in their Florida study. One of the standards used for identifying a plaintiffs' lawyer as a specialist was his or her involvement in at least four cases. SLOAN ET AL., supra note 30, at 170.

50. See supra text accompanying notes $43-45$ for a discussion of the logic for this combination of case attributes. 
A summary of all the variables examined is contained in Figure 1.

The Omitted Variable: Assessment of Liability

By design, our analysis does not include any measure of liability assessment. We did not distinguish among cases in which either the plaintiff's counsel, the defendant's counsel, or the insurer thought liability was either likely, unlikely, or uncertain. While there is much evidence that indicates that payment of money in a settlement is associated with a determination of liability by the insurer, ${ }^{51}$ this association has its own drawbacks as a useful predictor of outcomes, as discussed above. ${ }^{52}$ Our purpose instead was to see if predictions of case outcome can be made independently of liability assessment. Specifically, we wanted to see if an understanding of attorney attributes can predict case outcomes.

\section{Approach to Analysis}

Our analysis relies on descriptive statistics. Although the results of our bivariate statistical analyses are reported in the tables, small numbers in some cases make interpretation of results problematic. In these analyses, our discussion focuses on differences in percentages.

\section{FINDINGS}

The attorneys in our sample were overwhelmingly male- $88.8 \%$ of defense counsel and $87.6 \%$ of plaintiffs' counsel. Most had attended law school in the state of North Carolina ( $80.9 \%$ of plaintiffs' lawyers, $75 \%$ of defense lawyers, and $78.8 \%$ overall). The attorneys had been in practice a median of twenty years. Plaintiffs' lawyers were more numerous than defense lawyers, by a two to one margin (179 plaintiffs' lawyers and 89 defendants' lawyers). This reflects the tendency of insurers to rely on a relatively small group of attorneys to represent their insureds, as well as the absence of any formal barriers to representing a plaintiff in a medical malpractice lawsuit. The higher number of plaintiffs' lawyers meant that, on average, defense counsel handled more cases (3.91) than did plaintiffs' counsel (1.91).

Over sixty-nine percent of the cases involved more severe injuries, with $21.6 \%$ being death cases. In a substantial number of the cases (143 out of 348 cases or $40.1 \%$ ), a hospital defendant was involved, either alone or as a co-defendant.

As Table 1 shows, of the 348 cases in our total sample, settlements ${ }^{53}$ were the most frequent outcome $(51.5 \%)$, followed by abandoned cases. There were fifty-eight trials, for a trial rate of $16.7 \%$. Not every case that

51. Cheney et al., supra note 12 ; Peeples et al., supra note 19 , at $893-94$; Sloan \& Hsieh, supra note 7; Taragin et al., supra note 9.

52. See supra text accompanying notes 17-20.

53. "Settlement" in this context does not necessarily mean a payment of money to the plaintiff, as discussed supra text accompanying notes $40-41$. A "settlement" instead means the entry of either an order approving settlement by the court or a voluntary dismissal with prejudice. 
FIGURE 1

VARIABLES AND CODING

\begin{tabular}{lll}
\hline Dependent Variable & \multicolumn{1}{c}{ Definition } & \multicolumn{1}{c}{ Coding } \\
\hline Money Paid & $\begin{array}{l}\text { Cases in which money was } \\
\text { paid to the plaintiff, whether } \\
\text { in settlement or as the result } \\
\text { of a favorable jury verdict }\end{array}$ & $\begin{array}{l}0=\text { money not paid } \\
\text { a money paid }\end{array}$ \\
\hline
\end{tabular}

\begin{tabular}{ll}
\hline Independent Variables & Definition \\
\hline Severity of Alleged Injury & Less severe injuries included \\
& emotional only, insignificant \\
& injury, minor temporary disa- \\
& bility, and major temporary \\
disability & More severe injuries included \\
& minor permanent partial disa- \\
& bility, major permanent par- \\
tial disability, major & permanent total disability, \\
& grave permanent total disabil- \\
& ity and death \\
& Did Patient Die?
\end{tabular}

Hospital defendant

Gender

Law school attended

General experience of plaintiff's lawyer Independent Variables

Specific experience in medical malpractice litigation

Trial experience

A Seasoned attorney
Was at least one of the defendants a hospital?

What was the gender of plaintiff's lawyer?

Where did plaintiff's lawyer attend law school?

Number of years since plaintiff's lawyer was admitted to practice

Number of medical malpractice cases handled by plaintiff's lawyer during the study period

Number of medical malpractice cases handled by defendant's lawyer during the study period

Did plaintiff's lawyer conduct at least one trial during the study period?

Did plaintiff's lawyer (1) handle at least four medical malpractice cases, (2) conduct at least one trial, and (3) attend an in-state law school?

Did defendant's lawyer (1) $\quad 0=$ no, as to 1,2 , or 3

handle at least four medical $1=$ yes, as to 1,2 , and 3 malpractice cases, (2) conduct a least one trial, and (3) attend an in-state law school?

Coding

$0=$ less severe

$1=$ more severe

$0=$ patient did not die

$1=$ patient died

$0=$ no

$1=$ yes

$0=$ female

$1=$ male

$0=$ out of state

$1=$ in the state of North

Carolina

$0=$ less than 10 years

$1=$ more than 10 years

$0=$ less than four cases

$1=$ four or more cases

$0=$ less than four cases

$1=$ four or more cases

$0=$ no

$1=$ yes

$0=$ no, as to 1,2 , or 3

$1=$ yes, as to 1,2 , and 3 
TABLE 1

OUTCOMES OF MEDICAL MALPRACTICE CASES

\begin{tabular}{lcr}
\hline & Number & Pct \\
\hline Abandoned Cases & 77 & $22.1 \%$ \\
Involuntary Dismissals summary judgment, court order & & \\
dismissing complaint & 16 & $4.6 \%$ \\
Judgment following trial & 45 & $13.2 \%$ \\
Settlement & 178 & $51.1 \%$ \\
Other (outcome unknown or unclear) & 31 & $8.9 \%$ \\
Total & 348 & $99.9 \%$ \\
\hline
\end{tabular}

went to trial ended in a judgment. Some cases settled after the trial started, and several cases were dropped after the trial started. Of the forty-eight cases that progressed as far as a jury verdict, plaintiffs won ten $(20.8 \%)$ and defendants won thirty-eight $(79.2 \%) .{ }^{54}$ Money was paid to the plaintiff (through settlement or verdict) in slightly more than half $(50.7 \%)$ of the cases. We report payment and trial rates for each variable.

\section{A. Case Attributes: Severity of InJury and Hospital Defendants}

As Table 2 shows, money was more likely to be paid in settlement for cases in which serious injury was alleged $(53.6 \%$ compared to $44.0 \%)$. In addition, the trial rate was somewhat higher for such cases $(20.4 \%$ compared to $14.3 \%$ ), although plaintiff's success rate at trial was only slightly higher $(21.6 \%$ compared to $18.2 \%)$. Cases involving death were even more likely to result in the payment of money: over two-thirds of such cases $(68.2 \%)$ ended with money being paid to the plaintiff. This result is statistically significant $(\mathrm{p}<0.001$, phi $=-0.188) .{ }^{55}$ Death cases resulted in trial less often than other cases. Success rates at trial for death and nondeath cases were similar at $20 \%$ and $21.1 \%$, respectively.

When a hospital was a defendant-either alone or as a codefendantthe likelihood of a monetary payment increased (see Table 2). Money was paid in hospital cases more than half the time (55.9\%). In non-hospital cases, money was paid less than half the time $(46.7 \%)$. Although trial rates for hospital and non-hospital cases were about the same $(16.4 \%$ ver-

54. Judgment was actually entered in only forty-six of the cases. In the two other cases, despite a jury verdict, a settlement was reached.

55. Measures of association are reported in the Tables. In the words of a leading text:

The statistical significance of a relationship observed in a set of sample data

$\ldots$ is always expressed in terms of probabilities. "Significant at the .05 level $(p<.05)$ " simply means that the probability that a relationship as strong as the observed one can be attributed to sampling error alone is no more than 5 in 100 . Put somewhat differently, if two variables are independent of one another in the population, and if $\mathbf{1 0 0}$ probability samples are selected from that population, no more than 5 of those samples should provide a relationship as strong as the one that has been observed.

Earl Babbie, The Practice of Social Research (10th ed. 2003). 
TABLE 2

EFFECT OF CASE ATTRIBUTES ON PAYMENT AND TRIAL RATES

\begin{tabular}{|c|c|c|c|c|c|c|c|c|c|}
\hline \multirow[t]{2}{*}{ Variable } & \multicolumn{3}{|c|}{$\begin{array}{c}\text { Money Paid } \\
\text { to Plaintiff }\end{array}$} & \multicolumn{3}{|c|}{ Trial Rate } & \multicolumn{3}{|c|}{$\begin{array}{c}\text { Plaintiff's Success } \\
\text { Rate at Trial }\end{array}$} \\
\hline & Number & Total & Pct & $\begin{array}{l}\text { No. } \\
\text { Trials }\end{array}$ & $\begin{array}{l}\text { Total } \\
\text { cases }\end{array}$ & Pct. & Won & Total & Pct. \\
\hline \multicolumn{10}{|l|}{ Severity of Injury } \\
\hline More severe & 113 & 211 & $53.6 \%$ & 45 & 221 & $20.4 \%$ & 8 & 37 & $21.6 \%$ \\
\hline $\begin{array}{c}\text { Less severe } \\
\text { Did Patient Die? }\end{array}$ & \multicolumn{9}{|c|}{ Did Patient Die? } \\
\hline $\begin{array}{l}\text { Yes } \\
\text { No }\end{array}$ & $\begin{array}{r}45 \\
105\end{array}$ & $\begin{array}{r}66 \\
230\end{array}$ & $\begin{array}{l}68.2 \% \\
45.7 \%\end{array}$ & $\begin{array}{l}11 \\
47\end{array}$ & $\begin{array}{r}71 \\
251\end{array}$ & $\begin{array}{l}15.5 \% \\
18.7 \%\end{array}$ & $\begin{array}{l}2 \\
8\end{array}$ & $\begin{array}{l}10 \\
38\end{array}$ & $\begin{array}{l}20.0 \% \\
21.1 \%\end{array}$ \\
\hline \multicolumn{10}{|l|}{$\begin{array}{l}\text { Was a Hospital a } \\
\text { Defendant? }\end{array}$} \\
\hline Yes & 71 & 127 & $55.9 \%$ & 22 & 134 & $16.4 \%$ & 6 & 19 & $31.6 \%$ \\
\hline No & 79 & 169 & $46.7 \%$ & 36 & 188 & $19.1 \%$ & 4 & 29 & $13.8 \%$ \\
\hline
\end{tabular}

sus $19.1 \%$ ), the plaintiffs' success rates were not. Plaintiffs were more than twice as likely to obtain a favorable verdict in hospital cases as they were in non-hospital cases (31.6\% versus $13.8 \%$ ).

\section{B. Attorney Attributes: Gender, Law School Attended, General EXPERIENCE AND Malpractice CASE EXPERIENCE}

Statistical analysis of gender differences is necessarily limited, due to the small number of female attorneys in our sample. Nonetheless, as indicated in Table 3, female plaintiffs' attorneys obtained money for their clients more frequently than their male counterparts $(57.6 \%$ versus. $49.8 \%)$. In addition, female plaintiffs' attorneys went to trial more often ( $25 \%$ compared to $17.6 \%$ ) and were more frequently successful at trial, winning $33.3 \%$ of the time compared to $19 \%$ for men (Table 3 ).

It made very little difference whether the plaintiff's attorney had attended a law school in or out of the state of North Carolina, in terms of obtaining money for clients (Table 3). However, attorneys educated outof-state tried cases less frequently (15.5\% versus $19.6 \%)$, and prevailed at trial less often than those who had attended a law school in North Carolina $(9.1 \%$ compared to $25.7 \%)$.

Neither payment rates nor trial rates were greatly affected by the general experience level of plaintiffs' counsel, although younger lawyers fared somewhat better than older lawyers in obtaining money at trial ( $20 \%$ compared to $12.9 \%$ ) (Table 3 ). However, the story changes when medical malpractice case experience is considered. Money was more likely to be paid in cases in which plaintiffs' counsel had handled four or more medical malpractice cases (57.1\% compared to $46.3 \%$ ). This result approaches statistical significance $(\mathrm{p}=0.07)$. When favorable jury verdicts are disregarded and only monetary settlements are considered, the result 
TABLE 3

EFFECT OF ATTORNEY ATTRIBUTES ON PAYMENT AND TRIAL RATES

\begin{tabular}{|c|c|c|c|c|c|c|c|c|c|}
\hline \multirow[t]{2}{*}{ Variable } & \multicolumn{3}{|c|}{ Money Paid } & \multicolumn{3}{|c|}{ Trial Rate } & \multicolumn{3}{|c|}{$\begin{array}{c}\text { Plaintiff's Success } \\
\text { Rate at Trial }\end{array}$} \\
\hline & Number & Total & Pct & $\begin{array}{l}\text { No. } \\
\text { Trials }\end{array}$ & $\begin{array}{l}\text { Total } \\
\text { cases }\end{array}$ & Pct. & Won & Total & Pct. \\
\hline \multicolumn{10}{|l|}{ Gender } \\
\hline Male & 128 & 257 & $49.8 \%$ & 50 & 284 & $17.6 \%$ & 8 & 42 & $19.0 \%$ \\
\hline Female & 19 & 33 & $57.6 \%$ & 8 & 32 & $25.0 \%$ & 2 & 6 & $33.3 \%$ \\
\hline \multicolumn{10}{|l|}{ Law School attended } \\
\hline In-state & 106 & 207 & $51.2 \%$ & 44 & 224 & $19.6 \%$ & 9 & 35 & $25.7 \%$ \\
\hline Out-of-state & 34 & 66 & $51.5 \%$ & 11 & 71 & $15.5 \%$ & 1 & 10 & $9.1 \%$ \\
\hline \multirow{2}{*}{\multicolumn{10}{|c|}{$\begin{array}{l}\text { Years in Practice- } \\
\text { Plaintiff's Counsel }\end{array}$}} \\
\hline & & & & & & & & & \\
\hline Older & 107 & 212 & $50.5 \%$ & 37 & 228 & $16.2 \%$ & 4 & 31 & $12.9 \%$ \\
\hline Younger & 28 & 53 & $52.8 \%$ & 13 & 57 & $22.8 \%$ & 2 & 10 & $20.0 \%$ \\
\hline \multicolumn{10}{|l|}{ Medical Malpractice } \\
\hline \multicolumn{10}{|l|}{ Case Experience } \\
\hline More case experience & 68 & 119 & $57.1 \%$ & 25 & 127 & $19.7 \%$ & 5 & 20 & $25.0 \%$ \\
\hline Less case experience & 82 & 177 & $46.3 \%$ & 33 & 195 & $16.9 \%$ & 5 & 28 & $17.8 \%$ \\
\hline \multicolumn{10}{|l|}{ Trial experience } \\
\hline Yes & 72 & 138 & $52.2 \%$ & $\mathrm{n} / \mathrm{a}$ & & & $\mathbf{n} / \mathbf{a}$ & & \\
\hline No & 75 & 152 & $49.3 \%$ & $\mathbf{n} / \mathbf{a}$ & & & $\mathrm{n} / \mathrm{a}$ & & \\
\hline
\end{tabular}

becomes statistically significant $(\mathrm{p}<0.05)$. Trial rates for plaintiffs' lawyers with more medical malpractice experience were only slightly higher $(19.7 \%$ compared to $16.9 \%)$, but their success rate at trial was noticeably higher $(25 \%$ compared to $17.9 \%)$. Table 3 further indicates that whether plaintiffs' counsel had trial experience had little effect, in and of itself, on the frequency of payment. Plaintiffs' counsel with medical malpractice trial experience were only slightly more likely to obtain compensation for their clients $(52.2 \%$ versus $49.3 \%)$.

Thus far only the impacts of single variables on payment and trial rates have been considered. This approach is only the first step, however, if we are to isolate the characteristics of the most successful plaintiffs' attorneys. Plaintiffs' lawyers, after all, have a number of attributes that can be measured. When several variables are considered in combination, a sharper picture emerges.

Table 4 shows the results when three attorney-specific attributes-medical malpractice case experience, trial experience, and law school attended-are considered in combination. Plaintiffs' counsel with both substantial malpractice case experience and trial experience who had attended one of the five in-state law schools did much better than plaintiffs' lawyers who lacked one or more of these attributes. They obtained money for their clients in almost three-fourths of their cases $(72.7 \%)$ and went to trial twice as often as other plaintiffs' lawyers. Both results are statistically significant $(\mathrm{p}<0.001$ and $\mathrm{p}<0.01$, respectively). Furthermore, their success rate at trial was much better as well- $38.5 \%$ versus $15.2 \%$. 
TABLE 4

PAYMENT AND TRIAL RATES: SEASONED ATTORNEYS

\begin{tabular}{|c|c|c|c|c|c|c|c|c|c|}
\hline & \multicolumn{3}{|c|}{$\begin{array}{c}\begin{array}{c}\text { Success Rate } \\
\text { at Trial }\end{array} \\
\end{array}$} & \multicolumn{3}{|c|}{ Money Paid } & \multicolumn{3}{|c|}{ Trial Rate } \\
\hline & Pct. & No. & Total & Pct. & No. & Total & Won & Total & Pct. \\
\hline $\begin{array}{l}\text { Seasoned Attorneys } \\
\text { Less Seasoned Attorneys }\end{array}$ & $\begin{array}{l}30.6 * \% \\
15.5 \%\end{array}$ & $\begin{array}{r}40 \\
100\end{array}$ & $\begin{array}{r}55 \\
218\end{array}$ & $\begin{array}{l}72.7 * * \% \\
45.9 \%\end{array}$ & $\begin{array}{l}19 \\
36\end{array}$ & $\begin{array}{r}62 \\
197\end{array}$ & $\begin{array}{l}5 \\
5\end{array}$ & $\begin{array}{l}13 \\
33\end{array}$ & $\begin{array}{l}38.5 \% \\
15.2 \%\end{array}$ \\
\hline
\end{tabular}

$* \mathrm{p}<0.01$

** $\mathrm{p}<0.001$

The difference in outcomes goes beyond payment and trial rates, however. Seasoned plaintiffs' attorneys - that is, attorneys with medical malpractice case experience, trial experience, and a law degree from an instate law school - very seldom gave up on their cases. Only three out of a total of sixty-two cases handled by seasoned attorneys were dropped unilaterally $(4.8 \%)$ (see Table 5). The abandonment rate for other plaintiffs' lawyers was much higher (69 out of 233 cases or $29.6 \%$ ). In addition, an adverse summary judgment or involuntary dismissal by court order never happened in cases handled by seasoned attorneys.

TABLE 5

CASE OUTCOMES FOR PLAINTIFFS' LAWYERS

\begin{tabular}{lccccc}
\hline & \multicolumn{2}{c}{$\begin{array}{c}\text { Less-Seasoned } \\
\text { Plaintiffs' Lawyers }\end{array}$} & & \multicolumn{2}{c}{$\begin{array}{c}\text { More Seasoned } \\
\text { Plaintiffs' Lawyers }\end{array}$} \\
\cline { 2 - 3 } & Number & Pct. & & Number & Pct. \\
\hline Abandoned Cases & 69 & $29.6 \%$ & & 3 & $4.8 \%$ \\
$\begin{array}{l}\text { Involuntary Dismissals } \\
\text { (summary judgment, court }\end{array}$ & & & & & \\
Order dismissing complaint) & 13 & $5.6 \%$ & & 0 & $0.0 \%$ \\
Judgment following trial & 32 & $13.7 \%$ & & 12 & $19.4 \%$ \\
Settlements & 116 & $49.8 \%$ & & 46 & $7.2 \%$ \\
Other & 3 & $1.3 \%$ & & 1 & $1.6 \%$ \\
Total & 233 & $100.0 \%$ & & 62 & $100.0 \%$ \\
\hline
\end{tabular}

The picture can be made clearer still. The outcome of a contested case cannot be described only in terms of the attributes of plaintiffs' counsel or only in terms of defense counsel. After all, lawyers do not get to choose opposing counsel. What happens when lawyers of disparate levels of experience confront each other? When medical malpractice case and trial experience and law school attributes are also applied to defense counsel, the differences in payment and trial rates become even more pronounced. The results are displayed in Table 6, which shows four possible combinations: (1) cases handled by plaintiffs' lawyers with trial and malpractice case experience who had attended a law school in-state but opposed by defense lawyers lacking one or more of these attributes; (2) cases in which both the plaintiffs' lawyers and the defense lawyers had 
trial and case experience and had attended law school in-state; (3) cases in which defense counsel had trial and case experience and had attended law school in-state but was opposed by plaintiffs' lawyers who lacked one or more of those attributes; and (4) cases in which neither plaintiff's lawyer nor defense counsel had trial and case experience and had attended law school in-state.

TABLE 6

MATCHES AND MISMATCHES

\begin{tabular}{|c|c|c|c|c|c|c|c|c|c|}
\hline & \multicolumn{3}{|c|}{$\begin{array}{c}\text { Money Paid } \\
\text { to Plaintiff } \\
\end{array}$} & \multicolumn{3}{|c|}{ Trial Rate } & \multicolumn{3}{|c|}{$\begin{array}{c}\text { Plaintiff's Success } \\
\text { Rate at Trial } \\
\end{array}$} \\
\hline & Number & Total & Pct. & Number & Total & Pct. & Won & Total & Pct. \\
\hline $\begin{array}{l}\text { Seasoned plaintiff's lawyer, } \\
\text { less seasoned defense } \\
\text { lawyer }\end{array}$ & 20 & 25 & $80.0 \%$ & 8 & 28 & $28.6 \%$ & 2 & 4 & $50.0 \%$ \\
\hline $\begin{array}{l}\text { Seasoned plaintiff's lawyer, } \\
\text { seasoned defense lawyer }\end{array}$ & 19 & 27 & $70.4 \%$ & 8 & 31 & $25.8 \%$ & 3 & 7 & $42.9 \%$ \\
\hline $\begin{array}{l}\text { Less seasoned plaintiff's } \\
\text { lawyer, seasoned defense } \\
\text { lawyer }\end{array}$ & 46 & 116 & $39.7 \%$ & 22 & 121 & $18.2 \%$ & 2 & 20 & $10.0 \%$ \\
\hline $\begin{array}{l}\text { Less seasoned plaintiff's } \\
\text { lawyer, Less seasoned } \\
\text { defense lawyer }\end{array}$ & 52 & 96 & $54.2 \%$ & 13 & 106 & $12.3 \%$ & 3 & 12 & $25.0 \%$ \\
\hline
\end{tabular}

A mismatch in favor of the plaintiff led to payment, either in settlement or at trial eighty percent of the time. In contrast, a mismatch in favor of the defendant led to payment, either in settlement or at trial, less than forty percent $(39.7 \%)$ of the time. This result is statistically significant $(\mathrm{p}<0.001)$. Of equal importance, however, is the fact that mismatches in the defendant's favor were much more common (116 cases) than mismatches that favored the plaintiff ( 25 cases) by a margin of over four to one. The difference in outcome by matches and mismatches is statistically significant at the 0.001 level.

Trial rates were lowest $(12.3 \%)$ when neither counsel had trial and case experience and a law degree from an in-state law school. Success rates at trial for plaintiffs' counsel were highest $(50 \%)$ when a mismatch favored the plaintiff and were lowest $(10 \%)$ when a mismatch favored the defendant. Abandonment rates were lowest when a mismatch favored the plaintiff. Abandonment rates were highest when a mismatch favored the defendant ( 38 abandonments out of 121 cases where mismatch favored defendant or $31.4 \%$ ).

Case attributes provide an additional insight. More seasoned plaintiffs' counsel tended to handle only cases alleging more severe injuries (Table 7). The difference in selection of cases by severity between less seasoned and more seasoned plaintiffs' counsel was statistically significant $(\mathrm{p}<0.01$, $\mathrm{phi}=0.171$ ). 
TABLE 7

SEASONED ATTORNEYS AND CASE ATTRIBUTES

\begin{tabular}{|c|c|c|c|c|c|c|}
\hline \multirow[t]{2}{*}{ Variable } & \multicolumn{3}{|c|}{$\begin{array}{c}\text { Less Seasoned } \\
\text { Plaintiffs' Lawyers }\end{array}$} & \multicolumn{3}{|c|}{$\begin{array}{c}\text { More Seasoned } \\
\text { Plaintiffs' Lawyers } \\
\end{array}$} \\
\hline & Number & Total & Pct. & Number & Total & Pct. \\
\hline \multicolumn{7}{|c|}{ Severity of Injury } \\
\hline More Severe & 169 & 246 & $68.7 \%$ & 56 & 64 & $87.5 * * \%$ \\
\hline Less Severe & 77 & 246 & $31.3 \%$ & 8 & 64 & $12.5 \%$ \\
\hline \multicolumn{7}{|c|}{ Was a Hospital a Defendant? } \\
\hline Yes & 98 & 253 & $38.7 \%$ & 33 & 67 & $49.3 \%$ \\
\hline No & 155 & 253 & $61.3 \%$ & 34 & 67 & $50.7 \%$ \\
\hline
\end{tabular}

$* * \mathrm{p}<0.01$

In addition, more seasoned plaintiffs' lawyers were more likely to sue hospitals-either alone, or as one of several named defendants. This last observation takes on more importance when one last connection is made. Hospitals were much more likely to be involved as defendants in cases involving the patient's death (30.8\% compared to $15.1 \%)$ (Table 8$)$, and death cases were much more likely to result in payment to the plaintiff (see Table 2).

TABLE 8

HOSPITALS AND DEATH CASES

\begin{tabular}{lccccc}
\hline & \multicolumn{5}{c}{ Did Patient Die? } \\
\cline { 2 - 6 } & Yes & Pct. & No & Pct. & Total \\
\hline Was a Hospital a defendant? & & & & & \\
Yes & 44 & $30.8 \%$ & 99 & $69.2 \%$ & 143 \\
No & 31 & $15.1 \%$ & 174 & $84.9 \%$ & 205 \\
\hline$p<0.001$ & & & & &
\end{tabular}

Case attributes can also be considered in combination. What happens, for example, to cases alleging a serious injury and involving a hospital as a defendant? Table 9 provides the results. When both a serious injury was alleged and a hospital was a named defendant (high percentage cases), payment of money to the plaintiff became much more likely- $60.4 \%$ versus $45.9 \%$. The difference is statistically significant $(\mathrm{p}<0.05$, $\mathrm{phi}=0.136)$. Such cases were, furthermore, significantly more likely to be handled by seasoned plaintiffs' lawyers than by less seasoned lawyers $(43.9 \%$ versus $28 \%$ ), as Table 10 shows. This difference is significant at the 0.05 level, phi $=0.140$ (see Table 10).

\section{DISCUSSION}

When considered in isolation, few factors were strongly linked to the ultimate payment of money to the plaintiff. Only death cases and the case experience of plaintiffs' counsel were reliable indicators of payment. 
TABLE 9

PAYMENT AND TRIAL RATES: SERIOUS INJURY CASES WITH A HOSPITAL DEFENDANT

\begin{tabular}{|c|c|c|c|c|c|c|c|c|c|}
\hline & \multicolumn{3}{|c|}{$\begin{array}{c}\text { Money Paid } \\
\text { to Plaintiff }\end{array}$} & \multicolumn{3}{|c|}{ Trial Rate } & \multicolumn{3}{|c|}{$\begin{array}{c}\text { Plaintiff's Success } \\
\text { Rate at Trial }\end{array}$} \\
\hline & Number & Total & Pct. & Number & Total & Pct. & Won & Total & Pct. \\
\hline $\begin{array}{l}\text { Serious Injury Cases with } \\
\text { a Hospital Defendant } \\
\text { All Other Cases }\end{array}$ & $\begin{array}{l}58 \\
90\end{array}$ & $\begin{array}{r}96 \\
196\end{array}$ & $\begin{array}{l}60.4^{* \%} \\
45.9 \%\end{array}$ & $\begin{array}{l}18 \\
40\end{array}$ & $\begin{array}{r}98 \\
220\end{array}$ & $\begin{array}{l}18.4 \% \\
18.2 \%\end{array}$ & $\begin{array}{l}5 \\
5\end{array}$ & $\begin{array}{l}15 \\
33\end{array}$ & $\begin{array}{l}33.3 \% \\
15.2 \%\end{array}$ \\
\hline
\end{tabular}

$* \mathrm{p}=0.02$

TABLE 10

CASE SELECTION: SEASONED ATTORNEYS AND ATTRACTIVE CASES

\begin{tabular}{|c|c|c|c|c|c|c|}
\hline & \multicolumn{3}{|c|}{$\begin{array}{c}\text { Less-Seasoned } \\
\text { Plaintiffs' Lawyers } \\
\end{array}$} & \multicolumn{3}{|c|}{$\begin{array}{c}\text { More Seasoned } \\
\text { Plaintiffs' Lawyers } \\
\end{array}$} \\
\hline & Number & Total & Pct. & Number & Total & Pct. \\
\hline $\begin{array}{l}\text { Serious Injury Cases with a Hospital } \\
\text { Defendant } \\
\text { All Other Cases }\end{array}$ & $\begin{array}{r}70 \\
180\end{array}$ & $\begin{array}{l}250 \\
250\end{array}$ & $\begin{array}{l}28.0 \% \\
72.0 \%\end{array}$ & $\begin{array}{l}29 \\
37\end{array}$ & $\begin{array}{l}66 \\
66\end{array}$ & $\begin{array}{l}43.9 * \% \\
56.1 \%\end{array}$ \\
\hline
\end{tabular}

$* p<0.02$

More severe injuries and the presence of a hospital as a party defendant increased the likelihood of payment, but not dramatically. The general experience level of plaintiff's counsel and the law school attended by plaintiff's counsel did not make much difference, nor did the trial experience or gender of plaintiff's counsel.

\section{A. The Attributes of Seasoned Plaintiffs' Lawyers}

When attorney attributes are considered in combination, however, the picture becomes clearer. Cases handled by seasoned attorneys-attorneys who had handled at least four medical malpractice cases, who had conducted at least one medical malpractice trial, and who had attended law school in North Carolina-resulted in a payment to the plaintiff almost three-fourths of the time. Cases handled by seasoned attorneys were twice as likely to go to trial, and the odds of prevailing at trial, although still less than fifty percent, were much better than the odds faced by plaintiffs represented by less seasoned attorneys. In short, seasoned attorneys simply did better than their less seasoned counterparts, by several measures.

Seasoned attorneys, then, represent the most successful category of plaintiffs' lawyers. Why might this be so? A closer examination of the three attributes of seasoned attorneys provides some answers.

The key attribute of seasoned attorneys is substantial medical malpractice case experience. Plaintiffs' lawyers who had handled four or more medical malpractice cases were much more likely to obtain money for their clients than their less experienced counterparts. When jury verdicts 
for the plaintiff are excluded, and only settlements for money are considered, the difference in results is even more striking. Case experience makes a difference. The positive effect of experience certainly comports with common sense. Obtaining money in settlement of a disputed case is largely a function of bargaining. Bargaining is a skill, and as such, one would expect improvement as one gains experience. More specifically, there is evidence that judgment accuracy improves with experience in bargaining. ${ }^{56}$ Judgment accuracy is of obvious value to a bargainer. In order to be successful, one will be expected to assess the strengths and weaknesses not only of one's own case, but also the strengths and weaknesses of the opponent's case. In addition, plaintiffs' attorneys must be able to assess the attractiveness of any offer in settlement that the insurer may make. These are decisions informed by experience. In making these decisions, plaintiffs typically rely heavily on the advice of counsel. ${ }^{57}$ It should therefore not be surprising that experience on the plaintiffs' counsel side is associated with higher rates of payment. One either gets better in obtaining payment for claims of medical malpractice, or one takes up a different specialty. However, our data indicate that it is not enough to be experienced in general. It is specific, medical malpractice case experience that makes the difference.

In short, with case experience comes greater case picking expertise. Because of their case experience, seasoned attorneys are better equipped to spot likely "winners." A review of Table 10 bears this conclusion out. Seasoned attorneys rarely abandon their cases. They choose carefully, and they do not second guess their choices.

Yet greater medical malpractice case experience alone does not account for the differences in performance by seasoned plaintiffs' lawyers. Results further improve for plaintiffs when trial experience is factored into the definition of "seasoned" attorney. The fact that seasoned attorneys went to trial more often, and succeeded at trial more often, suggests that trial experience is quite valuable. The increased positive effect that trial experience has on plaintiffs' outcomes suggests something else as well. Reputation matters. The insurers' decisions about whether to settle or defend medical malpractice cases are made against the backdrop of trial prediction. ${ }^{58}$ The fact that the plaintiff's lawyer has trial experience makes his or her professed willingness to go to trial in a given case more believable, since he or she has done it before. The demonstrated willingness to take cases to trial, thereby imposing additional costs and risks on the insurer, serve to make the settlement demands of the plaintiff's counsel more credible. ${ }^{59}$ After all, medical malpractice litigation is largely a specialty practice, ${ }^{60}$ often characterized by repeat players in the form of

56. Leigh Thompson, The Influence of Experience on Negotiated Performance, $26 \mathrm{~J}$.

EXPERIMENTAl SOC. Psychol. 528, 542 (1990).

57. KRITZER, supra note 28 , at 63,125 .

58. Gross \& Syverud, supra note 21; Peeples et al., supra note 19, at 887-88, 893-94.

59. CARLIN, supra note 24, at 78-79; Rosenthal, supra note 25 , at 59.

60. See supra text accompanying notes $47-48$. 
opposing counsel on both sides. ${ }^{61}$ Insurers and defense counsel will know whether a particular plaintiffs' lawyer has a record of obtaining money in settlement and a record of taking cases to trial. It may well be that the defendants' bargaining posture is affected by that knowledge. ${ }^{62}$ In other words, success breeds success. It is the strong that survive.

The connection that in-state legal training has to plaintiffs' lawyers' success is harder to generalize about, although its additive effect on outcomes is clear. A high percentage of students who attend law school in North Carolina stay in North Carolina. ${ }^{63}$ Attendance at an in-state law school leads to relationships with fellow students who will also practice in North Carolina. Connections are often formed and reputations are often made while in law school. In other words, attendance at a law school in state may be an early step in a networking process that facilitates cooperation among lawyers. It is also true that many students attend law school in North Carolina simply because they grew up in North Carolina. It may be that a familiarity with the state-reinforced by attendance at an instate law school-reduces the risk of being perceived as an outsider, as someone "not from around here" who must be treated with a measure of suspicion. ${ }^{64}$ There may also be a benefit in sounding like a local, particularly with juries.

\section{B. Matches and Mismatches}

The contrast in case outcomes was starkest when mismatches occurred-when a seasoned attorney was paired with a less seasoned advocate. Very simply, plaintiffs did best when their lawyer was seasoned and defense counsel was not. Defendants did best when their lawyer was seasoned and plaintiff's counsel was not. When a mismatch favored the plaintiff, money was paid eighty percent of the time. When a mismatch favored the defendant, money was paid less than forty percent of the time. Success rates at trial followed a similar pattern. Therefore, it is not only the identity of the plaintiff's lawyer that matters. The identity of opposing counsel makes a difference as well. Still, this observation needs to be qualified. The reason for this becomes apparent when the numbers behind the matches and mismatches are considered. It is an infrequent event when a plaintiff's lawyer is opposed by a less seasoned defense law-

61. KRITZER, supra note 28 , at 94,124 .

62. See Carlin, supra note 24, at 78-79; Marc Galanter, Why the "Haves" Come Out Ahead: Speculations on the Limits of Legal Change, 9 LAw \& SoC'Y REv. 95, 99 (1974).

63. For example, in 1996 (the earliest year for which the data are available) a total of 770 law students received their law degree from the five North Carolina law schools. Of that number, 413 applied to take the North Carolina bar exam that summer $(53.6 \%)$. By individual schools, the percentage of graduates taking the North Carolina bar exam ranged from a high of $88.3 \%$ (Campbell) to a low of $12.8 \%$ (Duke). SECTION OF LEGAL EduCAtion and Admissions to tHE Bar, ABA Approved Law Schools (1998 ed.).

64. As part of our interviewing process with attorneys, we routinely asked about their recollections of opposing counsel. When a lawyer wanted to question the relative skill of opposing counsel, it would frequently be expressed in terms of being "not from around here," or "he's not from around here and doesn't know." 
yer. The converse situation is much more common. Quite simply, plaintiffs and their lawyers do not get to choose their opposing counsel. The insurer makes the decision about which lawyer to retain after the identity of plaintiff's counsel is known. It would be surprising, indeed, if relatively inexperienced defense lawyers were retained to oppose more battle-hardened plaintiffs' lawyers.

What seems clear is that novice players play against long odds. One pays a price to gain experience, in terms of less favorable outcomes or less desirable cases. Mismatches favor the more seasoned counsel, and the mismatches more frequently favor the defense side.

\section{The Role of Case Attributes}

When considered in combination, two case attributes-severity of injury and hospital involvement-are quite predictive of payment. Specifically, cases alleging a more severe injury and naming a hospital as a party defendant were much more likely to result in payment of money to the plaintiff than cases lacking one or both of those attributes. Which is the more important indicator of payment-case attributes or attorney attributes?

A review of our findings leads to the conclusion that it is the attorney attributes that are the critical indicators. The fact that cases alleging serious injury and those involving hospitals are handled disproportionately by seasoned attorneys is the key. ${ }^{65}$ Attorneys pick cases, not vice versa. Cases of more serious injury are more attractive than cases of less serious injury since they can be expected to settle (or be tried) for more money than cases of less serious injury. A similar dynamic may be at work for cases involving hospitals. Suing a hospital presents several advantages for a plaintiff's counsel. First, hospitals are institutions, not individuals. Their potential for winning sympathy from a jury is likely to be much less than the sympathy a defendant physician might attract. Second, unlike physicians' policies, most hospital malpractice insurance policies come with high deductibles. ${ }^{66}$ Thus, hospitals bear more economic risk in insisting on trial than physicians do. Third, unlike physicians, hospitals are not subject to the constraints imposed by the National Practitioner Data Bank. ${ }^{67}$ Money paid in settlement to a plaintiff by a hospital need not be reported to the Data Bank. In contrast, any amount, regardless how modest, paid on behalf of a physician must be reported. This built-in disincentive to settle cases operates on physicians but not hospitals. The conclusion to be drawn, however, is more basic. Attorney attributes are at least as important as case attributes. The oft-cited point ${ }^{68}$ that severity determines pay-

65. See Daniels et al., supra note 26, at 29.

66. Samuel Gross \& Kent Syverud, Getting to No: A Study of Settlement Negotiations and the Selection of Cases for Trial, $90 \mathrm{MICH}$. L. Rev. 319, 363 (1991).

67. See supra note 46.

68. Brennan et al., supra note 14 . Brennan et al.'s finding that only severity of injury predicted payment to claimants-as opposed to the apparent existence of negligence-has been frequently cited. See, e.g., sources cited supra note 16. This is somewhat puzzling for 
ment, then, is at least incomplete, if not misleading.

The system turns on an ability to pick cases shrewdly, and for that task, seasoned attorneys are much better equipped. ${ }^{69}$ When a potential case is first brought to him or her, the plaintiffs' attorney must make a determination whether the case has potential monetary value. This determination, of course, is made necessary because of the way plaintiffs' attorneys are compensated; plaintiffs' counsel agree to take cases in return for a percentage of any moneys recovered. Whether a case has monetary value depends on two factors: the perceived odds that liability can be established and the likely amount of any recovery. Case experience helps the plaintiffs' attorney evaluate these two factors. ${ }^{70}$ The fact that more seasoned plaintiffs' lawyers handled cases of greater severity more frequently than other plaintiffs' lawyers is evidence of the value of greater case experience. Over $87.5 \%$ of the cases handled by more seasoned plaintiffs' lawyers involved allegations of more severe injuries, compared to $68.7 \%$ of the cases handled by less seasoned plaintiffs' lawyers. ${ }^{71}$ In general, the monetary value of a case increases with the severity of the injury. Therefore, seasoned plaintiffs' lawyers are more likely to select cases in which injury is more severe. The much higher abandonment rate for less seasoned plaintiffs' lawyers also suggests that seasoned attorneys are more likely to pick cases in which payment will be made.

It also seems that success breeds success. Plaintiffs' lawyers who have demonstrated an ability to recover money for their clients may expect to be sought out by potential plaintiffs. The likelihood of referrals from nonspecialists also increases. Previous research provides evidence that potential plaintiffs do, in fact, tend to find the lawyers who have had success in the past either on their own, or with the help of referring lawyers. ${ }^{72}$ Our research supports this view. A relatively small number of plaintiffs' lawyers handled a relatively large number of the cases in our sample. ${ }^{73} \mathrm{Po}$ tentially lucrative cases find the more successful plaintiffs' attorneys, wherever they might be located. Counsel's geographic proximity to the plaintiff does not seem to be very important.

several reasons. First, as Brennan and his co-authors subsequently observed in a later article, their finding is at odds with what most other researchers have found. See David Studdert et al., Beyond Dead Reckoning: Measures of Medical Injury Burden, Malpractice Litigation, and Alternative Compensation Models from Utah and Colorado, 33 IND. L. REV. $1643,1654-65(2000)$. Second, the finding was ultimately based on an examination of only forty-six claims records-the end product, in a sense, of the much larger Harvard Medical Practice Study, which was a population based study, not a claims-made study. Brennan et al.'s findings were replicated in Utah and Colorado, but again the number of claims studied was quite small (18).

69. Daniels et al., supra note 26 , at $38-39$.

70. Kritzer, supra note 21 , at 800,808 .

71. $\mathrm{p}=0.003$.

72. SlOAN ET AL., supra note 30, at 73-76.

73. See supra text accompanying notes 47-48. 


\section{Death Cases}

The very high rate of settlement for death cases is not particularly surprising. It may be that insurers are not anxious to take death cases to trial. It may also be that in death cases, the family of the deceased patient tend to be more interested in a prompt resolution to the case and are particularly disinclined to relive the circumstances of the decedent's death in a trial. The empirical evidence offers an additional insight not as dependent on speculation. Cases alleging more serious injury and cases in which hospitals are a defendant, pay more often. Death cases fit both criteria. More than half of the death cases (44 out of 75 death cases or $58.7 \%$ ) involved hospitals. ${ }^{74}$

\section{CONCLUSION}

We have examined the outcomes of medical malpractice cases on the basis of a number of different factors other than assessment on the merits. It should come as no surprise that the most successful plaintiffs' attorneys are the ones with the greatest amount of relevant experience. It should come as some comfort to lawyers that attorney qualifications do seem to matter. There is a value to being skilled. In contrast, it may come as little comfort to defendants to realize that factors other than the merits affect outcomes.

Who the plaintiffs' attorney is does matter. The effectiveness of plaintiffs' attorneys can be measured in a systematic, empirical way. We need not rely on inference and anecdote alone. The system, from the perspective of the plaintiffs' lawyer, works in a rational way. Less seasoned attorneys pay a price for their lack of experience. More seasoned attorneys can expect to enjoy the rewards that come from their greater experience.

74. Table 8. $\mathrm{p}<0.001$. 